\title{
PARTISIPASI MASYARAKAT DALAM PROGRAM DANA DESA DI KECAMATAN MAPPAKASUNGGU SULAWESI SELATAN
}

\author{
Ika Widiastuti ${ }^{*}$ \\ Pandu Adi Cakranegara ${ }^{2}$ \\ 1Universitas Krisnadwipayana, Indonesia \\ 2Universitas Presiden, Indonesia \\ iwidiastuti86@gmail.com ${ }^{1 *}$ \\ pandu.cakranegara@president.ac.id ${ }^{2)}$
}

\author{
Kata Kunci: \\ [Partisipasi,pengawasan, \\ Dana desa]
}

\begin{abstract}
Latar belakang penelitian adalah partisipasi masyarakat di Kecamatan Mappakasunggu Sulawesi Selatan dalam program dana desa belum maksimal. Hal ini disebabkan minimnya pendidikan masyarakat dan minimnya pengetahuan kesadaran masyarakat tentang program dana desa. Tujuan penelitian untuk meningkatkan pengetahuan dan partisipasi masyarakat dalam program dana desa. Metode yang digunakan adalah angket (kuesioner).

Pengabdian dilaksanakan oleh warga desa dan tim di Kecamatan Mappakasunggu, Sulawesi Selatan. Hasil penelitian adalah setelah warga desa mengikuti kegiatan penyuluhan yang dihadiri oleh para kepala desa menunjukkan bahwa partsipasi masyarakat dalam program dana desa mengalami peningkatan. Hal ini dapat diketahui bahwa warga desa hadir dalam musyawarah desa, menyampaikan aspirasi, pertanyaan dan keluhan serta ikut melaksanakan serta mengawasi jalannya program dana desa. Program tersebut untuk menambah usaha produktif warga desa sehingga dapat membantu perekonomian dan mensejahterakan masyarakat desa di Kecamatan Mappakasunggu Sulawesi Selatan.
\end{abstract}

\section{Pendahuluan}

Berdasarkan hasil penghitungan Dana Alokasi Umum (DAU) penduduk kabupaten Takalar Sulawesi Selatan tahun 2011, yaitu jumlah pria lebih sedikit daripada wanita. Di Kabupaten Takalar Sulawesi Selatan mempunyai jumlah penduduk sekitar 272.316 jiwa.

Selain itu tahun 2011, jumlah penduduk di Kabupaten Takalar Sulawesi Selatan berjumlah 481 jiwa/km2. Jumlah penduduk terbanyak di Kecamatan Galesong Utara berjumlah 2.404 jiwa/km2, sedangkan jumlah penduduk paling rendah di Kecamatan Polombangkeng Utara sejumlah 218 jiwa/km2.

Tabel 1. Jumlah Penduduk Berdasarkan Jenis Kelamin Tahun 2011

\begin{tabular}{lccc}
\hline \multicolumn{1}{c}{ Kecamatan } & Pria & Wanita & Jumlah \\
\hline Mangarabombang & 17.658 & 19.400 & 37.058 \\
Mappakasunggu & 7.238 & 8.053 & 15.291 \\
Sanrobone & 6.294 & 7.116 & 13.410 \\
\hline
\end{tabular}




\begin{tabular}{lcccc}
\hline Polombangkeng Selatan & & 12.754 & 14.269 & 27.023 \\
Pattallassang & & 16.704 & 18.374 & 35.079 \\
Polombangkeng Utara & & 22.476 & 23.810 & 46.286 \\
Galesong Selatan & 11.453 & 12.641 & 24.094 \\
Galesong & & 18.532 & 19.215 & 37.747 \\
Galesong Utara & & 17.794 & 18.534 & 36.328 \\
\hline & $\mathbf{2 0 1 1}$ & 130.903 & 141.413 & 272.316 \\
\multicolumn{1}{c}{ Kabupaten Takalar } & $\mathbf{2 0 1 0}$ & 129.599 & 140.004 & 269.603 \\
& $\mathbf{2 0 0 9}$ & 123.944 & 134.030 & 257.974 \\
& $\mathbf{2 0 0 8}$ & 123.173 & 131.981 & 255.154 \\
& $\mathbf{2 0 0 7}$ & 121.468 & 130.802 & 252.270 \\
\hline
\end{tabular}

Sumber : BPS Kabupaten Takalar, 2013

Berdasarkan UU Nomor 6 Tahun 2014 yang berkaitan dengan desa, sehingga desa dapat mengurus pembangunan, tata pemerintahan, keuangan guna untuk kesejahteraan dan kualitas desa. Pemerintah desa harus dapat mengimplementasikan prinsip keterbukaan serta pertanggungjawaban kepada warga desa (Filguiras, 2015).

Pemerintah desa dituntut membuat laporan realisasi penggunaan dana desa. Desa di Kecamatan Mappakasunggu Sulawesi Selatan yaitu Desa Camba-camba dan Desa Pa'batangan yang mempunyai kompetensi dalam perikanan dan tambang pasir.

Pada zaman dahulu, warga desa bermatapencaharian sebagai pengrajin gerabah. Namun pada kenyataannya kualitas produktif pengrajin gabah belum mengalami peningkatan yang signifikan. Hal ini membuat para pengrajin gabah beralih mata pencaharian sebagai pedagang.

Sekarang ini, terdapat 10 kepala keluarga yang bekerja sebagai pengrajin gerabah. Namun ada juga warga masyarakat desa yang beralih pekerjaan karena belum mampu bersaing dengan peralatan rumah tangga lainnya. Di Kecamatan Mappakasunggu Sulawesi Selatan, infrastruktur sudah memadai untuk mempermudah aktivitas warga masyarakat desa. Hal ini menunjukkan bahwa kurang dari tiga tahun kebijakan dana desa sudah dilaksanakan.

Berdasarkan survey di lapangan, menunjukkan bahwa masih kurangnya partisipasi masyarakat dalam program dana desa di Kecamatan Mappakasunggu Sulawesi Selatan. Hal ini disebabkan kurang pengetahuan dan kurangnya pendidikan mengenai program dana desa oleh warga masyarakat desa. Oleh karena itu perlu dilakukan sosialisasi dan penyuluhan kepada warga desa yaitu masyarakat dan kepala desa. Rumusan masalah penelitian yaitu bagaimana cara supaya partisipasi masyarakat desa dalam program dana desa dapat meningkat di Kecamatan Mappakasunggu Sulawesi Selatan. Sedangkan tujuan penelitian yaitu dapat mengetahui tingkat partisipasi aktif masyarakat desa dalam program dana desa serta dapat mengetahui konsep dari partisipasi masyarakat dan program dana desa. 


\section{Partisipasi Masyarakat}

Partisipasi masyarakat yang tinggi merupakan ciri daerah yang mandiri dan maju. Masyarakat diharapkan dapat mempunyai kesadaran yang tinggi untuk berpartisipasi aktif dan transparan, dapat memberikan respon dan saran.

Sudriamunawar (2006:54) menyatakan bahwa pelaksanaan pembangunan dapat berhasil apabila terdapat partisipasi dari masyarakat, karena dapat membantu kemampuan yang ada daerah sehingga dapat mewujudkan pembangunan yang efektif dan efesien.

Siti Irene Astuti D. (2009:17 34-35) berpendapat partisipasi masyarakat merupakan kepedulian keikutsertaan warga dalam pengambilan keputusan dan membuat kebijaksanaan. Sedangkan Sudriamunawar (2006:49) menyebutkan bahwa partisipasi masyarakat yaitu : (1) ikut serta dalam menentukan strategi, arah dan kebijaksanaan pembangunan yang dilakukan pemerintah. (2) Ikut serta dalam tugas dan tanggung jawab program pembangunan. (3) ikut serta memetik manfaat pembangunan dengan adil dan merata.

Sudriamunawar (2006:49), partisipasi masyarakat sangat penting dalam pembangunan karena kinerja lebih berkualitas dan berkuantitas, dengan biaya yang terjangkau; dapat memberikan pelayanan, mewujudkan kebersamaan, kesatuan dan persatuan, dorongan untuk pembangunan berikutnya, serta dapat menambah pengetahuan masyarakat, memberikan kesadaran kepada masyarakat untuk mengatasi kemiskinan.

\section{Dana Desa}

Definisi desa berdasarkan UU Nomor 6 tahun 2014 sebagai sekelompok masyarakat yang mengurus dan mengatur masyarakat desa dan mempunyai batas wilayah. Untuk membiayai kegiatan pembangunan, pemerintahan, kemasyarakatan, pembinaan, desa membutuhkan dana desa. Sumber dana tersebut berasal dari APBN digunakan untuk desa, dikirim oleh APBD Kabupaten.

Tujuan dana desa yaitu negara dapat melindungi dan memantapkan desa menjadi mandiri, maju, kuat, adil, demokratis, sejahtera dan makmur serta dapat menanggulangi kemiskinan.

\section{Metode Pelaksanaan}

Pengabdian dilaksanakan di Kecamatan Mappakasunggu Sulawesi Selatan. Pengabdian dilaksanakan untuk meningkatkan ikut serta masyarakat desa dalam kegiatan dana desa serta pembangunan dan peningkatan kesejahteraan masyarakat warga desa di Kecamatan Mappakasunggu Sulawesi Selatan.

Pertama dalam kegiatan pengabdian, melakukan survey lapangan untuk menentukan tempat pengabdian dan penentuan jumlah peserta yang diundang. Kemudian melaksanakan koordinasi dengan para kepala desa untuk menentukan desa yaitu Desa Pa`batangan dan Desa Camba-camba yang dijadikan tempat untuk kegiatan pengabdian. Selain itu, kepala desa juga menghimbau kepada warga desa untuk hadir dalam musyawarah desa atau pengabdian. Berdasarkan hasil penelitian menunjukkan bahwa sebanyak 74 orang warga desa yang hadir dalam kegiatan pengabdian. 
Untuk mendapatkan informasi dan data mengenai tingkat pemahaman program dana desa, tim menyebarkan kuesioner selama penyuluhan kepada warga desa. Metode yang digunakan adalah ceramah atau penyuluhan guna membimbing warga desa Kecamatan Mappakasunggu Sulawesi Selatan supaya dapat berpartisipasi aktif dalam program dana desa.

Di dalam pelaksanaan kegiatan penyuluhan, diinformasikan mengenai dasar hukum program dana desa, peningkatan partisipasi warga desa serta melakukan pengawasan program dana desa. Warga desa juga dapat memberikan saran, pertanyaan, keluhan, kontribusi yang berkaitan dengan kebijakan dana desa. Hal ini dilakukan setelah tim melaksanakan penyuluhan. Penyuluhan tersebut dihadiri oleh para kepala desa. Kepala desa memberikan sambutan dan memberikan penghargaan kepada tim pengabdian masyarakat yang telah memberikan penyuluhan kepada warga desa di Kecamatan Mappakasunggu Sulawesi Selatan sehingga dapat menambah ilmu pengetahuan dan partisipasi masyarakat pada program dana desa dapat meningkat.

\section{Hasil dan Pembahasan}

Tujuan diadakannya penyuluhan yaitu supaya warga masyarakat desa Kecamatan Mappakasunggu Sulawesi Selatan dapat menambah ilmu pengetahuan dam wawasan, serta dapat memahami program dana desa, sehingga partisipasi masyarakat dapat meningkat.

Metode yang digunakan adalah dengan menyebarkan kuesioner kepada responden oleh tim dengan tujuan untuk dapat mengetahui seberapa persen jumlah warga masyarakat desa yang memahami mengenai dana desa dan jumlah persentase partisipasi masyarakat terhadap program dana desa sebelum diadakan penyuluhan. Berikut ini merupakan hasil dari jawaban responden sebelum dilaksanakan penyuluhan yaitu sebagai berikut (Lihat Tabel 2):

Tabel 2. Jawaban Responden Mengenai Pengetahuan dan Partisipasi Masyarakat Dana Desa (Sebelum Penyuluhan Dana Desa) di Kecamatan Mappakasunggu Sulawesi Selatan

\begin{tabular}{clcc}
\hline No. & \multicolumn{1}{c}{ Kegiatan } & Setuju & $\begin{array}{c}\text { Ragu- } \\
\text { ragu }\end{array}$ \\
\hline 1. & Memahami dana desa & $52 \%$ & $36 \%$ \\
2. & Memahami kegiatan dibiayai dana desa & $49 \%$ & $35 \%$ \\
3. & Hadir rapat desa & $45 \%$ & $0 \%$ \\
4. & Menyampaikan saran & $37 \%$ & $0 \%$ \\
5. & Berpartisipasi program dana desa & $33 \%$ & $0 \%$ \\
6. & Berkontribusi pelaksanaan dana desa & $15 \%$ & $32 \%$ \\
7. & Memantau implementasi program & $35 \%$ & $32 \%$ \\
& Peserta sekitar 74 orang & &
\end{tabular}

Sumber: Data sebelum penyuluhan dana desa, 2017

Kesimpulan data di atas adalah rendahnya pengetahuan masyarakat terhadap dana desa. Dari 74 peserta yang hadir, 54\% mengetahui mengenai dana desa di Kecamatan Mappakasunggu Sulawesi Selatan, 15\% yang terlibat dalam pelaksanaan program dana desa. 
Rendahnya tingkat pendidikan warga desa merupakan penyebab masyarakat kurang berpartisipasi mengenai program dana desa. Hal ini dapat diketahui setelah dilaksanakan wawancara kepada kepala desa. Selain itu, dalam rangka meningkatkan partisipasi masyarakat, maka kepala desa memasang pengumuman di kantor desa.

Dalam program pengabdian, Kepala Desa Kecamatan Mappakasunggu Sulawesi Selatan memberikan himbauan kepada warga desa untuk memberikan saran dan kritik terhadap program yang dilaksanakan, dan menghimbau supaya warga masyarakat untuk hadir dalam kegiatan musyawarah atau rapat mengenai pengelolaan dana desa.

Hasil dari kegiatan pengabdian masyarakat adalah adanya peningkatan partisipasi masyarakat dalam program dana desa serta untuk meningkatkan pengetahuan masyarakat mengenai dana desa sehingga dapat melakukan pengawasan dan dapat melaksanakan kegiatan dana desa. Setelah kegiatan penyuluhan dilakukan, maka dapat diketahui jawaban kuesioner dari responden yaitu sebagai berikut:

Tabel 3. Pengetahuan Masyarakat Mengenai Dana Desa (Setelah Penyuluhan) di Kecamatan Mappakasunggu Sulawesi Selatan

\begin{tabular}{clcc}
\hline No. & \multicolumn{1}{c}{ Kegiatan } & Setuju & Ragu-Ragu \\
\hline 1. & Memahami dana desa & $83 \%$ & $17 \%$ \\
2. & Memahami kegiatan dibiayai dana desa & $83 \%$ & $17 \%$ \\
3. & Hadir rapat desa & $90 \%$ & $10 \%$ \\
4. & Menyampaikan saran & $75 \%$ & $15 \%$ \\
5. & Berpartisipasi program dana desa & $75 \%$ & $10 \%$ \\
6. & Memantau implementasi program & $74 \%$ & $20 \%$
\end{tabular}

Peserta sekitar 74 orang

Sumber: Data setelah penyuluhan dana desa, 2017

Berdasarkan hasil penelitian yaitu pengetahuan dari masyarakat mengenai dana desa mengalami peningkatan yang signifikan. Hal ini dapat diketahui bahwa sebelum penyuluhan dilaksanakan, 52\% warga desa yang memahami tentang dana desa. Setelah dilaksanakan penyuluhan, sekitar $83 \%$ warga desa sudah memahami kebijakan dana desa. Selain itu, masyarakat berencana hadir rapat tentang program dana desa, sekitar $90 \%$ warga desa berencana akan hadir hadir dan sekitar $75 \%$ berencana memberikan saran.

Partisipasi dari masyarakat sangat penting dalam pelaksanaan program. Selain itu dukungan dari pemerintah juga menunjang dalam keberhasilan pelaksanaan program. Oleh karena itu supaya masyarakat percaya terhadap pelaksanaan program yang dilaksanakan, maka diperlukan transparansi dari pemerintah.

Selain penyuluhan, diperlukan pula sosialisasi dalam pengelolaan dana desa kepada masyarakat sehingga masyarakat dapat mengetahui, mengerti, memiliki kesadaran untuk berpartisipasi dan mengawasi pengelolaan dana desa. Berdasarkan jawaban dari responden menunjukkan bahwa $74 \%$ warga desa akan memantau dan mengawasi dana desa untuk pembangunan warga desa di Kecamatan Mappakasunggu Sulawesi Selatan. 


\section{Kesimpulan}

Pengabdian masyarakat di Kecamatan Mappakasunggu, Sulawesi Selatan dapat berjalan secara efektif setelah masyarakat diberikan penyuluhan, pengetahuan dan kesadaran masyarakat dalam mengawasi kegiatan dana desa maka masyarakat ikut berperan serta dalam kegiatan dana desa.

Warga desa memiliki harapan supaya kegiatan selanjutnya memenuhi saran dari masyarakat sehingga dapat meningkatkan kesejahteraan masyarakat desa di Kecamatan Mappakasunggu, Sulawesi Selatan.

\section{Referensi}

Filgueiras, F. 2015. "Transparency and Accountability: Principles and Rules for the Contruction of Publicity". Journal of Public Affairs. 19 June 2015.

Haryono, Sudriamunawar. 2006. Kepemimpinan, Peran Serta dan Produktivitas. Mandar Maju: Bandung.

Siti Irene Astuti D. 2009. Desentralisasi dan Partisipasi dalam Pendidikan. Yogyakarta: UNY

Biro Pusat Statistik Kabupaten Takalar Tahun 2015

Rencana Pembangunan Jangka Menengah Daerah Kabupaten Takalar Tahun 2013-2018.

Undang-undang Nomor 6 Tahun 2014 tentang Desa Undang-Undang Nomor 32 Tahun 2014 tentang Pemerintahan Daerah. 